\title{
チャンパ柌堂の壁龕の種類と配置について STUDY ON TYPES OF NICHE AND ITS DISPOSITION IN KÂLAN OF CHAMPA REMAIN
}

\author{
重 枝 豊* \\ Yutaka SHIGEEDA
}

\begin{abstract}
This study investigates, through field surveys, the types and disposition of Niches in Kâlan of Champa Remains. The Kingdom of Champa existed beteen 2th and 15th century and professed the Hindu and Buddhist faith.And as its religious building Kâlans were built of bricks. Consequently these two point mentiond below are clarified; 1.Principal type of niches are arranged at the three walls except entrance wall and on which other type of Niches are added, 2. All niches were made during the construction and located only important parts of chief kâlan.
\end{abstract}

Keywords: Champa, bricks, niche, $K$ âlan, Vietnam チャンパ、レンガ、壁䑾、祠堂、ベトナム社会主義共和国

\section{1. はじめに}

チャンパは 2 世紀から15世紀にかけて現ベトナム社会 主義共和国の中部に栄えた王国である。チャンパ王国*1 ではヒンドゥー教及び大乗仏教を国教として信奉した。 現存する宗教建築は、焼成レンガを主要材料とした組積 造である。その構筑においては、あらかじめ「柱型」*2、 「柱間壁」*3などの凹凸部を壁面に設けて積み上げてい ることに特徵がある。この柱形と柱間壁を多用して装飾 する壁面構成は、チャンパ建筑に共通する手法である。

チャンパの宗教建築の中心は「Kâlan」*4と呼ばれる 祠堂で、外壁面の柱型は花葉文粎等の装飾で飾られ、柱 型に挟まれた柱間壁にはヒンドゥー教彫像等のモチーフ が刻まれることが多い゙。装飾性の高い外壁面に対して、 内部壁面には凹所が設けられているだけで、彫刻類は施 されない。この内部の凹所を本稿では壁靇 ${ }^{* 6}$ と呼ぶ。壁 㓱はチャンパ建築の付属施設*7には設けられず主要建築 物である祠堂にのみ用いられている。内部壁面にほとん ど装飾が施されないことは、チャンパ建築の特徴の一つ であるが、壁霄自体も同様に装飾がされることが少ない。
また、この壁俞は造営後に壁面を削って設けられるの ではなく、造営時からそれぞれの壁㓱が計画され、施工 されていることが注目される。組積造の壁面に壁央を設 けることは施工手順の煩雑さだけでなく、構造的に脆弱 な部分を生み出すことになる。つまり、構造上重要な壁 面に空間を設ける技術は、チャンパ建筑の施工技術を解 明するための重要な意味を持っている。さらに、ヒンド ゥー教、仏教の主神を祀る中心建物である渰堂にのみ壁 青が計画されていることは、平面計画と内部での儀式な どが極めて緊密な関係を持っていたことが同われる。

これまで美術様式史を中心におこなわれたフランス極 東学院のチャンパ研究では、主に外壁面の装飾が注目さ れ、彫像や彫刻されたレリーフが様式判別の指標として

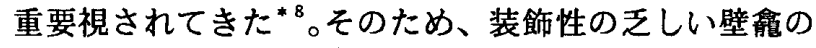
配置と構造に関してはこれまで言及されていない。

本稿では、チャンパ建築では唯一壁俞の設けられた建 物である祠堂を考察の対象とした。研究対象とした祠堂 は、伽藍を構成する主要な建筑であることから、創建年

* 日本大学理工学部建築学科 助手 $\cdot$ 工修

Dept. of Architecture, College of Science \& Technology, Nihon Univ., M. Eng. 
代が碑刻文等の第一次資料の研究等から明らかにされて

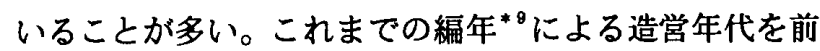
提とし、調查によって得た 55 棟の同堂の実測図を技術史 的な観点から分析した。平面計画と壁覦の配置計画の関 係を比較し、祠堂平面の変遷過程を解明することが本研 究の目的である*10。

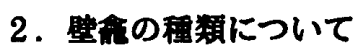

壁俞の検討に入る前に、壁能と関係するチャンパ建築 の祠堂の基本構成について整理しておきたい。

1 ）祠堂内部には、礼拝の対象物としてリンガや神像な どが安置されていた。そこでおこなわれる儀式は、 リンガなどを聖水で清めるもので、聖職者が中央に 安置されたリンガのなど信仰対象の周囲を巡回する ものであった。それら儀式の関連建築装置として壁 鸽が設けられだ・。

2 ) 䄇堂の出入口は 1 力所で、原則として入口は東面す るが、一部には入口が西面する場合もある。それ以 外に南面する特殊例も存在する。

3 ) 竸堂平面は主房と前房から構成される。主房に付属 した小規模な前房を持つ付属型、独立した構造で前 房を構成する延長型、拡幅型がある。（図一 1)

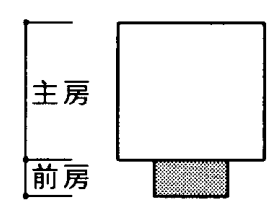

a）付属型

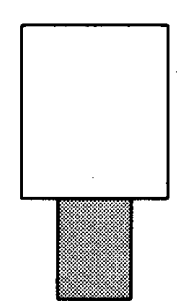

b) 延長型

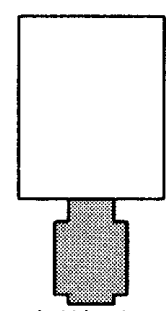

c) 搪幅型

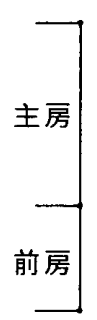

前房

図一 1 形状による前房の基本構成（概念図）
4) 建築材料として用いられたレンガは、焼成されたも ので、それぞれのレンガの大きさは一定していない。

5 ) レンガを積んだ外壁面には、未彫刻のまま据え置か れた部分が多くみられる。未彫刻部分は建物の背面 など目立たない部分に多いこと、彫刻作業を途中で 中止した箇所も多くみられる。このことから、レン ガ面に施された郕刻や彫像は、建物をいったん積み 上げた後に彫刻して、完成されたことがわかる。

以上のようなチャンパ建筑の特徽を踏まえた上で、间 堂内に設けられた壁兪の種類について分類して考察を加 えたい。壁㓱は壁面の一部に、単独で設けられる規模の 小さなむのや、大小複数の壁靇が組み合わされたものが ある。それらの中で、壁面の一部に設けられた小規模の ものを「小壁䧻」、床面から直接立ち上がる規模の大き

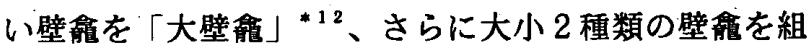

み合わせたものを「複壁霐」と呼ぶ。

事例数の多いのは小壁挦を単独で用いる場合で、「小 壁能型」と呼ぶ。大壁咸を用いる場合には、次の 3 つの タイプがある。一つ目は大壁䧻に小壁霘が併用される場

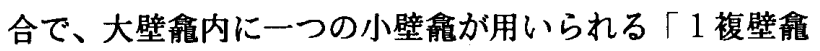

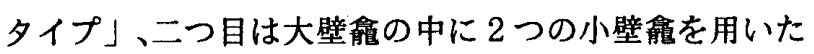
$「 2$ 複壁能タイプ」、三つ目は大壁䧻だけを設置する場 合でこれを「大壁霄単独タイプ」と呼ぶ*13。また、解堂 でありながら壁䧻の設けない「無壁䧻型」あみられる。
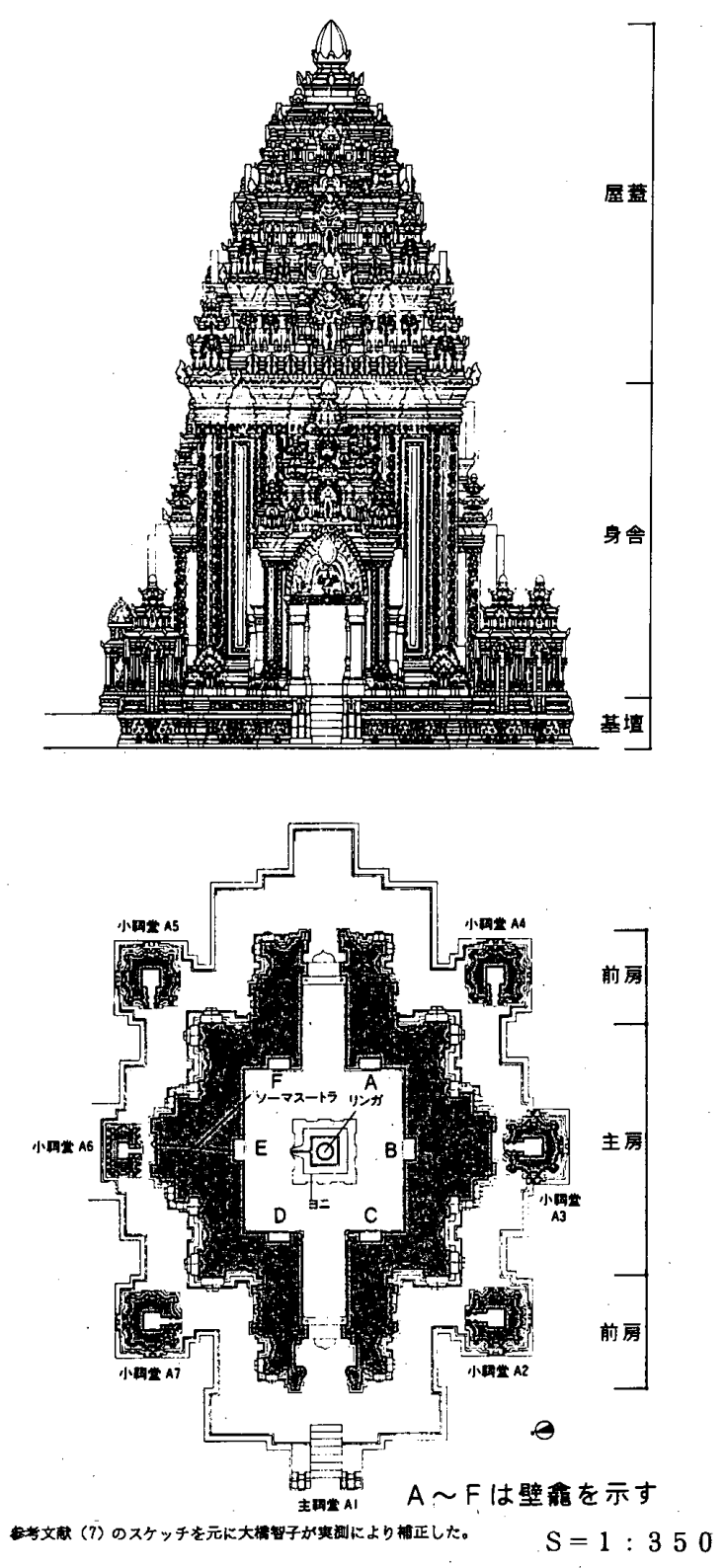

図一 2 ミソンA 1 ～A 7 復元平面図・立面図

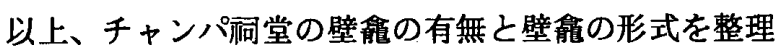

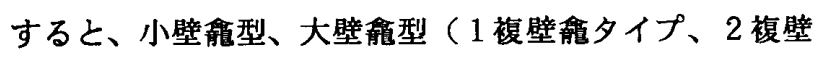

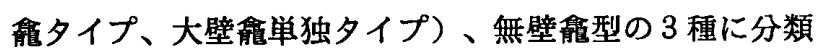


される。

壁鹘を構成する建築材料は、ミソン遗跡主柌堂 B 1 に ある砂岩製の壁央の事例を除く之、すべてが焼成された レンガ壁面に設けられている。
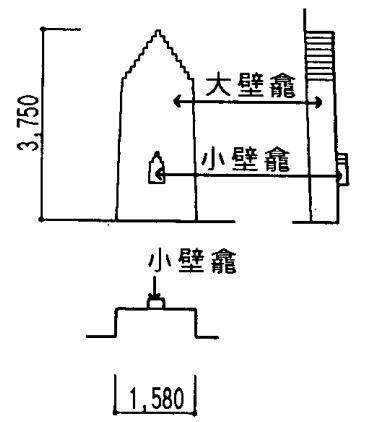
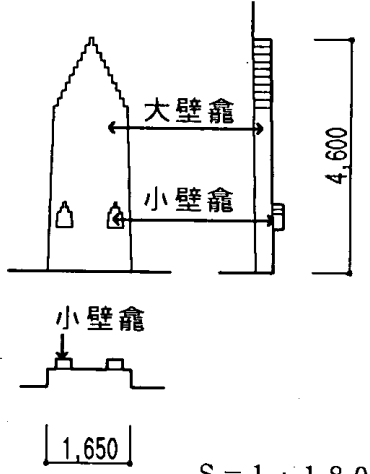

$S=1: 180$

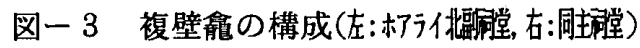

\section{3. 筀侴の槽造と装飾について}

次に、壁龍の構造と装飾を中心に検討したい。チャン パ建築の組積造の上首部は迫り出し構造 ${ }^{* 14}$ を用いて構 成されており、壁鸼も同様に迫り出し構造が用いられて いる。組積造においてこの工法を用いる場合、構造的制 約から壁龍の規模はレンガ部材の大きさによって制限を 受ける。そのため、大きな壁弇を設置するためには、一 つ一つのレンガの迫り出し幅を小さくする必要があり、 その結果壁䧻は高くなり、壁舶を構成する空間そのもの が大きくなる。これらの場合にレンガを迫り出す方法を 分類して検討すれば、レンガの構筑技術上での変化が考 察できる。

そこで、迫り出し構造の種類をその形状を中心に $2 つ$ に分けることにする。一つ目を「連続週減型壁俞」と呼 び、二つ目を「段首聥隇型壁俞」と呼ぶ。前者は、レン ガを一枚ずつ迫り出して頂部を支え、ピラミッド型の空 間を形成するもので、後者は、 $2 \sim 4$ 段のレンガごとに 迫り出して壁䧻を構成するものである。

さらに、壁俞装飾の有無によっても分類することがで きる。前述したようにチャンパ建筑の祠堂内部は極めて 装飾性に乏しい。しかし、一部に簡単な剞形文様のつい た事例がある。これを「装飾型壁嘎」とし、装飾の施さ れていないものと区分する。以下、壁雪の構造および装 飾について、それぞれ事例をあげて考察する。

\section{a )「連綍遇減型壁全」}

ミソンB 4（9世紀末、ドンジュオン様式）の北面に 残る壁䨟を代表的な事例として検討する。この袷堂は東

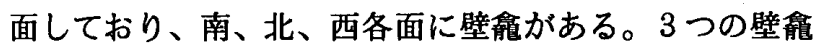
のうち北面の壁雮には修復の跡がなく創建時の状態が良
く残っている。この壁雹ではレンガを 9 段分内側に転ば せながらほぼ垂直に立ちあげ、そこから 6 段のレンガを 迫り出して壁䧻を構成している。迫り出し全幅 ${ }^{* 15}$ は556

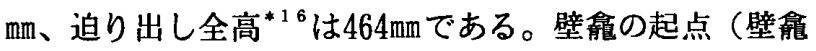
床面）と迫り出し起点までは51mmほど内転んでいる。各 首の派減をみると基本的にはレンガのそれぞれの聥減を 正確に決めて施工されたとは考えられない。小規模な施 工であるために、現場で調整しながら大まかに遁減の比 率を設定しているとみられる。迫り出し全幅に対する迫 り出し全高の比率は $1 ： 2$ 程度で、極めて緩やかである。

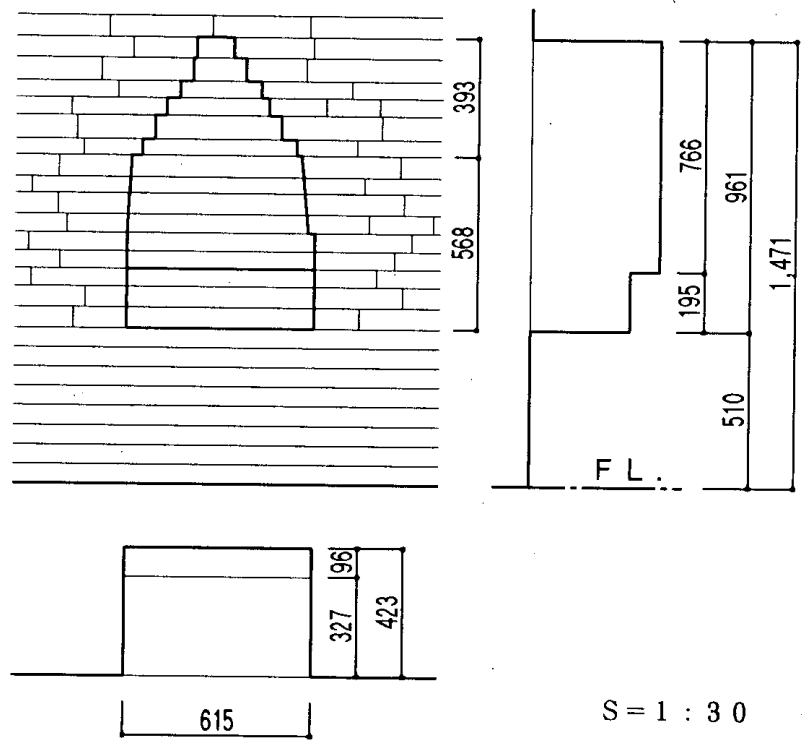

図ー4 ミソン B 4 北面壁弇実測図

\section{b ）「段居週減型壁盘」}

最も事例の多い壁裔の形式で、現存遺構の大部分はこ

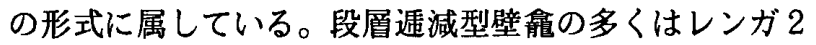
〜 4 段ごとに迫り出してゆくが、1つの段層部を構成す

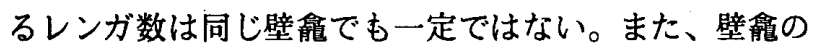
上部にゆくに従って 1 層を構成するレンガ数を減らして ゆく構成が一般的である。その実例をポー・ナガル主祠 堂を事例にあげて検討したい。

ポー・ナガル主间堂 (10世紀中葉、ミソン A 1 様式) 内部には 5 力所の壁龍が設置されているが、その中で保

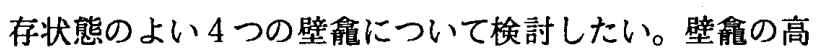
さは $668 \mathrm{~mm} \sim 756 \mathrm{~mm}$ 、幅は609 800 $\mathrm{mm}$ 、奥行は238〜284mm と様々である。各段層も基底面から 4 段、 3 段、 2 段、 2 段、1 段とレンガを派減させているが、壁俞 B、壁俞 Eではそのルールが崩れている。造営時に壁閏の規模が 正確に決められたのではなく、この場合にも連続派減型 と同様に施工時に現場調整の要素が高い。各段層部の迫 り出し幅も $42 \mathrm{~mm} \sim 87 \mathrm{~mm}$ と大きな開きがある。開口部の上 層にゆくにしたがって迫り出し幅は小さくなるが、それ も一律ではない。以上のことから壁飮の規模は一定の寸 
法基準が用いられたのではなく、レンガ枚数（13～14段） を造営時に設定し施工したとみられる。
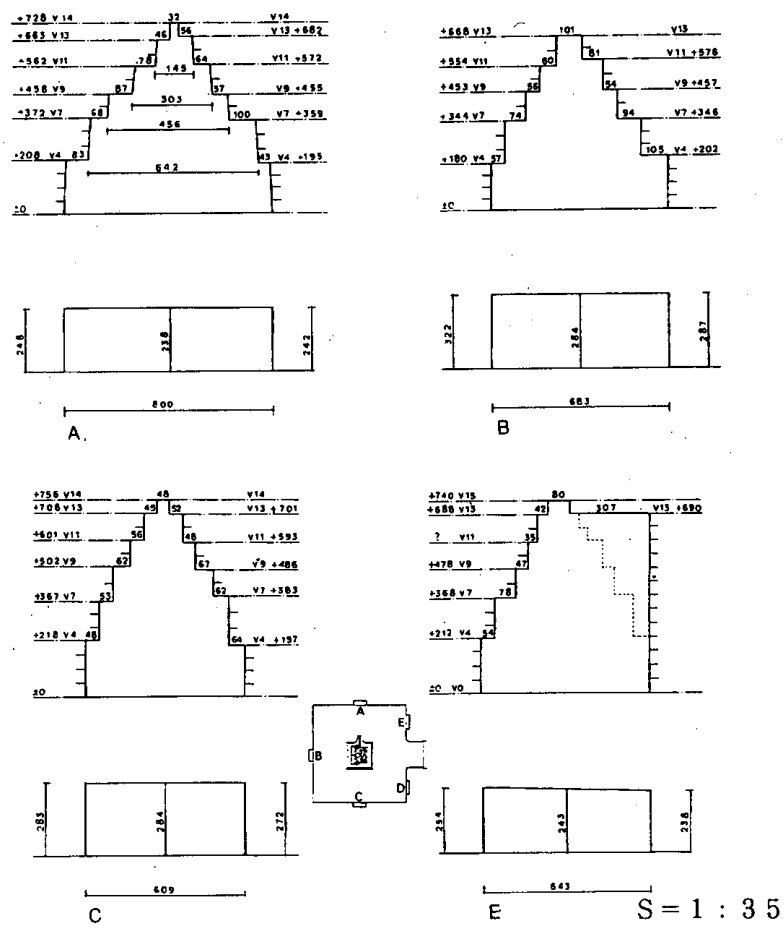

図ー5 ポー・ナガル主垌堂壁艟実測図
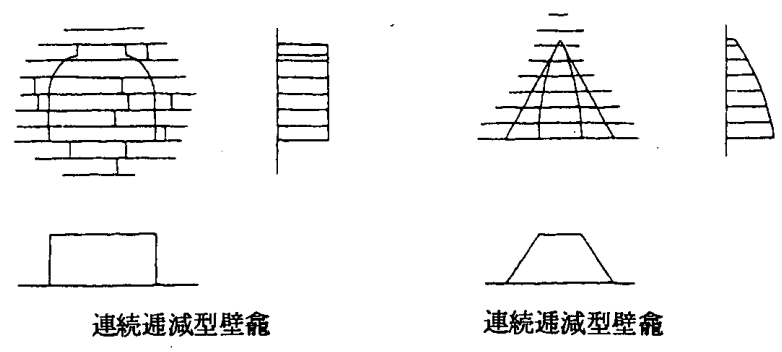

（ポー・ダム、8世紀）

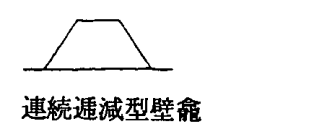

(ポー・クロン・ガライ、14世䄫切䫄)

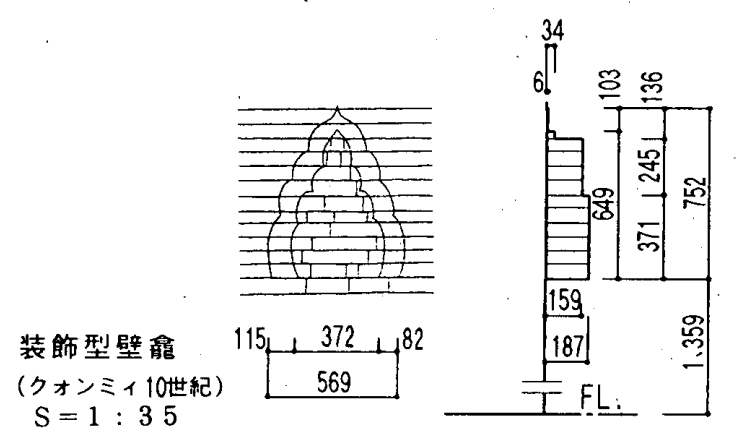

$S=1: 35$

図一6 各種の壁雪の実測事例

\section{c ）「装飾型壁全」}

クオンミー北副祠堂（10世紀初頭〜中葉、ミソン A 1 様式）において唯一みられる壁靇で、壁雹の外郭部に簡 素な繰型が設けられている。クオンミー主同堂（10世紀 中葉、ミソンA 1 様式) 、同南副䄑堂 (10世紀初頭、ミ ソンA 1 様式）においては段首派減型壁霞が用いられて
おり、同様の装飾はみられない。この遺跡は外壁の装飾 モチーフにジャワとクメールの様式との融合がみられる ことをPh. Sternが指摘している*17。このような装飾型 壁弇の存在は特異で隣国のクメール建築にも類例はみら れない*18。

\section{4. 各壁盘の眍固と特微}

\section{a ）「小塭盘型」}

小壁能型は祠堂壁面に数力所の小壁艟を設けたもので、 最も事例が多く、配置が多様である。小壁龍は通常床面 から $1 \mathrm{~m}$ 程度の位置に設けられる。小壁青は東面してい る哃堂では、主房の南、北、西の 3 面のほぼ中央に設け られる。この配置形式が小壁俞の配置事例として最も類 例が多い。この配置を「東面・3 壁俞タイプ」と呼ぶ。 現存事例は、ポー・ハイ主京堂、ミソンB 4 ・ E 5 ・C 6 の各副祠堂、ポー・ナガル南東・同南、同北西各副祠 堂、チェンダン主祠堂・同南副祠堂, 金塔、ポー・クロ ン・ガライ、ポー・ロメの各主祠堂などである。それぞ れの祠堂の造営時期は 8 世紀末から 17 世紀まで広く分布 している。

同様に西面している祠堂に東、南、北面に壁霡を配置 する形式を「西面・3壁俞夕イプ」と呼ぶ。この事例に は、ミソン $\mathrm{A} 1$ 主稬堂、ミソン $\mathrm{E} 6$ 副祠堂がある。さ らに、南面した特殊例として（南面・3 壁霄タイプ）、 ポー・ダム主秙堂、同南西副柌堂、同南東副洞堂がある。 これら 3 つのタイプでは入口側の壁面には壁能を設けな いことから、大きく 3 壁盘タイプとして分類する。

これに対して、3 壁䧻タイプの壁雹配置に加えて主房 内部側の片側又は両側に小壁䧻を加える事例がみられる。 西面した洞堂の西面南側に 1 力所壁泉を設けたミソンA 10 副䄇堂、ミソン $\mathrm{G} 1$ 主柌堂、東面した柌堂の東側壁面

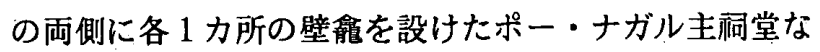
どである。さらに、チャンパ建築の京堂の中で唯一東西 両方向に入口を持つミソンA 1 では主房の南北壁面各 1 力所に加えて、主房東西壁面にそれぞれ 2 力所の壁艟を 配している。それに加えて、唯一前房の両面に壁㘛を設 けたミソンE 4 副稬堂がある。これらは出入口面などに 壁㓱を付加していることから「入口面壁雹付加タイプ」 と呼ぶ。

以上の他に、東面・3壁能タイプの変形として、北壁 面の中央にソーマスートラ*118設けるために、中央に 壁䧻を配置できずに壁䧻を両サイドに振り分けて設置し たと見られるミソンC 7 副祠堂（「分割設置タイプ」）、 西面して西面を除く 3 壁面に大小 3 力所の壁艟を配置し、 西面した壁面にも 2 力所計11力所壁愈のあるミソンF 1 主柌堂、東面する内部各壁面に各 2 力所の壁㲖があるミ ソンB 1 主渰堂（両者を「多壁能タイプ」）、また: 東 
面 3 壁俞型で西面南隅に床に接して壁㓱を加えて設けた クオンミ一北副祠堂（「変形付加タイプ」）など小壁䧻 型の中でも壁雹の多彩な配置がみられる。

\section{b ）「大等型」}

\section{$b-1\lceil 1$ 複壁垴タイプ」}

大壁俞の中に小壁䧻を 1 つ配置した事例である。1 複 壁タイプに属するのはホアライ北副祠堂とドンジュオン 主同堂の 2 棟だけである。ホアライ北副同堂は東面して おり南、北、西各面に 1 複壁能がある。ドンジュオン主 祠堂も東面し、南面、北面だけに 1 複壁䨟があった。ド ンジュオン主稬堂では東面の南北にそれぞれ 1 つの小壁 䧻が別に設けられているが、本来設けられるべき西側に は壁㨢がない。

まず、ホアライ北副祠堂（9世紀前半、ホアライ様式） について検討する。大壁霐の奥行は $540 \mathrm{~mm} \sim 640 \mathrm{~mm}$ 、幅は $1470 \mathrm{~mm} \sim 1580 \mathrm{~mm}$, 高さ3.75mの規模で、入口である東面を 除く 3 面に大壁龍が設置されている。ホアライ遺跡から 出土した遺物は少なく、これまでに確認されていないが、 この壁雹内には砂岩または木造の彫像が安置されていた 可能性が考えられる*20。大壁䧻の平面図(图-7)をみると、 壁弇のある 3 方には外部に壁体が突き出して配置されて いる。大壁䧻の形状と外部の突き出し部の構造には密接 な相関がみられる。つまり、レンガ造の内部の 3 万にそ れぞれ大きな控壁状の構造とすることにより、内部空間 を拡幅しようとした意図が読み取れる。これは構造上の 制約から平面が大きくなると、それにともなって拡大す る屋蓋を支えることができないため、内部を拡張するた めに大壁雹が設置されたと考えられる。

ドンジュオン主稬堂（9 世紀末、ドンジュオン様式） には 2 力所に大壁鹡が設けられているが、H. Parmentie の資料 ${ }^{* 21}$ から、内部に設置された祭壇の形状との関係 がみられる。ここでは唯一内部の祭壇の 3 方に階段が設 置されており、内部で儀式を執り行うためには大壁雪を 設けないと側面の通路の幅は $800 \mathrm{~mm}$ 程度で通行に制約が おきる。南面、北面の大壁俞に加えて、東面の入口に振 り分けて小壁龍か配置されており、小壁愈型でみた入口 面壁盘付加タイプと類似した構成を示している。西面に 大壁鶺がないのは、西側壁面に彫像が設置されていたた めである。他のヒンドゥー教を主神とする同堂には 2 方 向にだけに壁䨎を設けた事例はなく、大乗仏教を祀る寺 院として建立されたの宗教上の意図が反映されたとみら れる。さらに、ドンジュオン仏院内の他の 4 基の副祠堂 および 7 基の小京堂には、壁龍が設けられていない。 $b-2\lceil 2$ 複壁俞タイプ」

大壁䧻内に小壁鸼を2つ配置する事例で、ホアライ主 桐堂（9 世紀初頭、ホアライ様式）だけに見らる形式で あったが近年倒壊した。H. Parmentierの資料 ${ }^{23)}$ には、
明らかに現存している北副祠堂で用いたのと同じ表現を 用いて、大壁雹の中に 2 つ小壁龍が描かれている。基 本構造は 1 複壁䧻と同じ構成だが、大壁雪の奥行きは 1 複壁雹の事例よりも狭い。大壁雹の規模は、奥行 $450 \mathrm{~mm}$ $\sim 500 \mathrm{~mm}$ 、幅 $1400 \mathrm{~mm} \sim 1520 \mathrm{~mm}$, 高さ $4.4 \sim 4.6 \mathrm{~m}$ である。入口

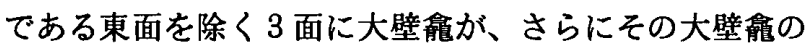
両脇に小壁龕か配置されていた。

$b-3$ 「大壁䧻単独夕イプ」

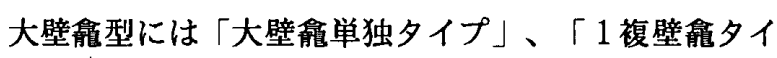
プ」「2複壁艄タイプ」があることは前述した。さらに、 この大壁俞型は規模の大きな「A」と、大壁鵃の形だけ が形䯚化した小規模な「B」に大別できる。「1複壁雹 タイプ」「2 複壁俩タイプ」はすべてAに属し、Bは 「大壁俞単独タイプ」にだけにみられる。大壁㓱単独夕 イプAには東面した同堂の 3 壁面に大壁雹のあるホアラ イ南副主祠堂（8世紀末、ホアライ様式）、西面して 3 つの大壁俞のあるミソン $\mathrm{A}^{*} 4$ 副祠堂（9 世紀末、ドン ジュオン様式）などの事例がある。大壁䧻単独タイプ B にはミソン C 1 主坃堂（10世紀中葉、ミソン A 1 様式）， ポー・ハイ北副祠堂 ( 8 世紀末〜 9 世紀前半、ポー・八 イ様式）などの事例がある。例えば大壁㓱単独タイプA

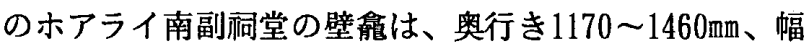
1220 1350mm と大規模であるのに対して、大壁㟫単独夕 イプB のミソンC 1 の場合は、奥行きが $91 \mathrm{~mm}$ 、幅 $900 \mathrm{~mm}$ と特に奥行きに規模の違いがみられる。大壁能型 $\mathrm{A}$ (大 壁䧻型のうち規模の大きなもの）は、チャンパ王国南部 の 9 世紀前半までのホアライ 3 遺構と、9 世紀末から 10 世紀末の北部の 3 遣構にみられる。それに対して大壁鵃 型 B（大壁龍型のうち壁㓱規模の小さなもの）は、南部 のポー・ハイ副備堂を除けば、ミソンC 1、チェンダン 北副祠堂、象牙塔（12世紀末、ビンディン様式）など王 国北部・中部にみられ、6 例中 4 例がビンティン様式 （11世紀初頭１3世紀初頭）に属している。また、ミソ ンA’ 4 を除いたすべてが東面している。

\section{c ）「無堲軎型」}

付属建築に壁䓹を設けた事例はないが、桐堂であるに もかかわらず壁雹のないものがある。その事例には、ミ ソン E 1、H 1 主闰堂、銀塔・ビンラム・クォンミー・ 雁塔・銅塔・バンアンの各主祠堂、ミソン F 3・A 2 ・ B 3 • C 5 の各副柌堂、フンタン主柌堂・同副同堂等 の17例である。これら無壁能型の同堂には、主呞堂で壁 䨎のないもの、副祠堂で壁龍のないものがあり、規模、 また建設時期によって壁俞の有無の差は判別できない。 あえて述べればビンティン地区に造営された间堂の多く が、都城中心部の丘上や城内に構筑された祠堂で、外壁 面にも装飾が少なく遠望が強く意識されている。これら は都市型の宗教施設と考えられており、王城(チャキェ 
表一 1 各祠堂の造営時期と壁䕍の形式

\begin{tabular}{|c|c|c|c|}
\hline 遭跡名称 & 造営時期 & 美術様式 & 壁峝の配置形式 \\
\hline \multicolumn{4}{|c|}{ a）小壁雷型の祠堂 } \\
\hline ポー・八イ主祠堂 & 8世紀末～9世紀前半 & ポー・ハイ & 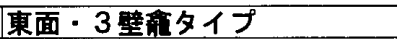 \\
\hline ミソンA 1 主祠堂 & 9世紀前半 & ホアライ & 西面・3壁费タイプ \\
\hline ポー・ダム主调堂 & 9 世紀前半 & ホアライ & 南面・3壁鼠タイプ \\
\hline ポー・ダム南副呞堂 & 9 世紀前半 & ホアライ & 東面・3壁弯タイプ \\
\hline ポー・タム南西副祠堂 & 9 世紀前半 & ホアライ & 南面・3壁盘タイプ \\
\hline ポー・ダム南東副祠堂 & 9 世紀前半 & ホアライ & 南面・3壁变タイプ \\
\hline ミソンF 1主泀堂 & 9世紀前半 & ホアライ & 西面・多壁露タイプ \\
\hline ミソンC 7副㓊堂 & 9 世紀末 & ドンジュオン & 㑿面・分割設置タイプ \\
\hline ミソンB 4 副哃堂 & 9 世紀末 & ドンジュオン & 東面・3壁眮タイプ \\
\hline ミソンE 5 副翮堂 & 10 世紀初頭 & ドンジュオン & 宩面・3墪霞タイプ \\
\hline ミソンA 10 副祠堂 & 10 世紀前半 & ドンジュオン & 西面 · 入口面壁弇付加タイプ \\
\hline ミソンA 1 主调堂 & 10 世紀前半 & ミソンA 1 & 東西面・入口面壁竞付加タイプ \\
\hline クォンミ一北副祠堂 & 10 世紀初頭～中葉 & ミソンA 1 & 東面・変形付加タイプ \\
\hline ポー・ナガル主翮堂 & 10 世紀中葉 & ミソンA 1 & 東面・入口面壁弇付加タイプ \\
\hline ミソンE 6 副同堂 & 10 世紀末 & ミソンA 1 & 西面・3壁霞タイプ \\
\hline ポー・ナガル北西副泀堂 & 10 世紀末 & ビンディン & 東面・3壁盒タイプ \\
\hline ミソンE 4 副司堂 & 11 世紀 & ビンディン & 西面 ・ 入口面壁解付加タイプ \\
\hline ミソンB 1 主丽堂 & 11 世紀 & ビンディン & 巢面・多壁盒タイプ \\
\hline ミソンC 6 副祠堂 & 11世紀 & ビンディン & 東面・3壁辞タイプ \\
\hline チェンダン主洞堂 & 11 世紀 & ビンディン & 宩面·3壁㓱タイプ \\
\hline チェンダン南副祠堂 & 11 世紀 & ビンディン & 東面・3壁弯タイプ \\
\hline ミソンG1主詞堂 & 11世紀初頭 12世紀前半 & ビンディン & 西面・入口面壁鬲付加タイプ \\
\hline ポー・ナガル南東副闹堂 & 12 1 13世紀 & ビンディン & 東面・3壁菲タイプ \\
\hline ポー・ナガル南副祠堂 & 12 13世紀 & ビンディン & 東面・3壁畣タイプ \\
\hline 金塔主袷堂 & 13 世紀 & ビンディン & 東面・3壁稚タイプ \\
\hline ポー・クロン・ガライ主祠堂 & 14 世紀初頭 & 後期様式 & 東面・3壁觓タイプ \\
\hline ポー・ロメ主螎堂 & 17世紀 & 後期槏式 & 東面・3壁霞タイプ \\
\hline
\end{tabular}

\begin{tabular}{|c|c|c|c|}
\hline \multicolumn{4}{|c|}{ b) 大壁峝型の祠堂 } \\
\hline b-1) 1複壁雍タイプ & & & \\
\hline ホアライ北副部堂 & 9 世紀前半 & ホアライ & 東面・1被壁盆タイプA \\
\hline ドンジュオン主祠堂 & 9 世紀末 & ドンジュオン & 東面・1複壁甾タイプA \\
\hline 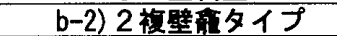 & & & \\
\hline ホアライ主泀堂 & 9世紀初頭 & ホアライ & 東面・2椱壁含タイプA \\
\hline b-3)大壁拿単独タイプ & & & \\
\hline ホアライ南副祠堂 & 8 世紀末 & ホアライ & 東面・大壁吝単独タイプA \\
\hline ポー・八イ北副祠堂 & 8世紀末～9世紀前半 & ポー・ハイ & 東面・大壁青単独タイプB \\
\hline ミソンA'4 副祠堂 & 9世紀末 & ドンジュオン & 西面・大壁竞単独タイプA \\
\hline クォンミー南副部堂 & 10 世紀初頭 & ミソンA 1 & 東面・大壁㔽単独タイプA \\
\hline ミソンC 1主泀堂 & 10 世紀中葉 & ミソンA 1 & 菓面・大壁紪独タイプB \\
\hline チェンダン北副祠堂 & 11～12世紀初頭 & ビンディン & 菓面・大壁弇単独タイプB \\
\hline 象牙塔主词堂 & 12 世紀末 & ビンディン & 宩面・大壁霍単独夕イプB \\
\hline 象牙塔南副祠堂 & 12 世紀末 & ビンディン & 宩面・大壁労独タイプB \\
\hline 象牙塔北副祠堂 & 12 世紀末 & ビンディン & 東面・大壁畣単独タイプB \\
\hline
\end{tabular}

\begin{tabular}{|c|c|c|c|}
\hline \multicolumn{4}{|c|}{ c）無壁型の祠堂 } \\
\hline ミソンE 1 主呞堂 & 8 世紀 & 古代様式 & 西面 \\
\hline ミソンF 3 副祠堂 & 9世紀前半 & ホアライ & 東面 \\
\hline ミソン $A^{\prime}$ 2 副泀堂 & 9 世紀前半 & ホアライ & 菓面 \\
\hline ドンジュオン小翮堂 & 9 世紀末 & ドンジュオン & 北面 \\
\hline クオンミ一主部堂 & 10 世紀中葉 & ミソンA 1 & 菓面 \\
\hline ミソンB 3 副司堂 & 10 世紀中葉 10世紀末 & ミソンA 1 & 西面 \\
\hline ミソンB 7 小祠堂 & 10 世紀中葉 10世紀末 & ミソンA 1 & 東面 \\
\hline ミソンC5副呞堂 & 10世紀中葉 11世紀初頭 & ミソンA 1 & 東面 \\
\hline 銀塔主祠堂 & 11世世紀初頭 & ビンティン & 東面 \\
\hline ビンラム主袷堂 & 11 世紀 & ビンディン & 宩面 \\
\hline 雁塔主词堂 & 11 世紀 & ビンディン & 巢面 \\
\hline ミソンH1主祠堂 & 12 世紀前半 & ビンディン & 菓面 \\
\hline パンアン主部堂 & 12 世紀 & ビンディン & 菓面 \\
\hline フンタン主泀堂 & 12 世紀末 & ビンディン & 東面 \\
\hline フンタン副祠堂 & 12 世紀末 & ビンディン & 菓面 \\
\hline 銅塔主祠堂 & 13世紀初頭 & ビンディン & 東面 \\
\hline トゥーティエン主呞堂 & 13 世紀末 & ビンディン & 菄面 \\
\hline
\end{tabular}

【Ph.Sternの英街軥年による 考文麻 (8)】

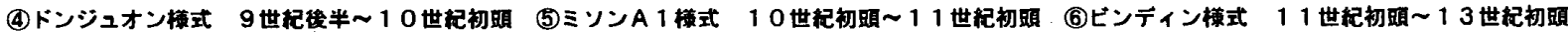
(1)後期様式 13 世䄫以降 


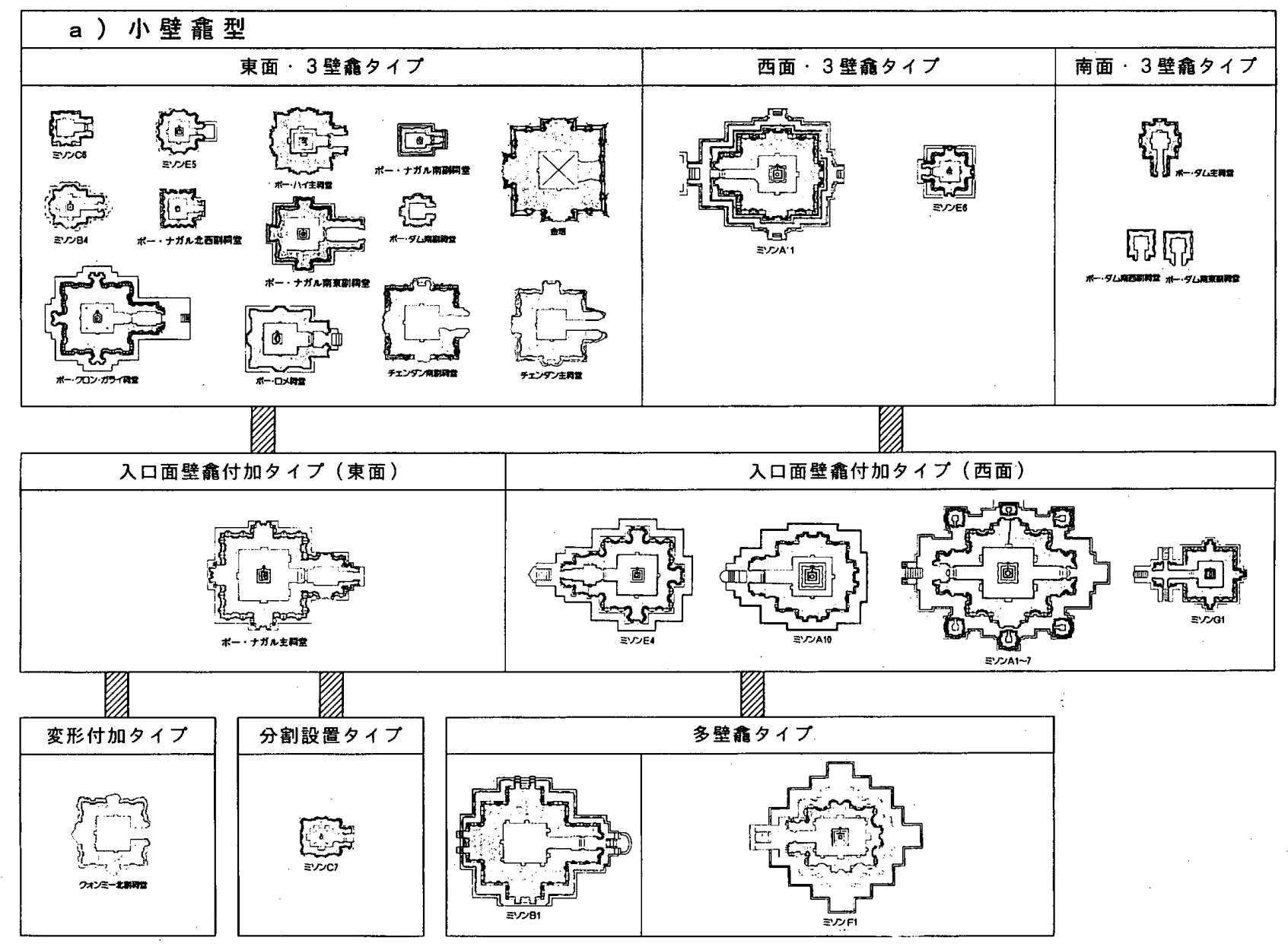

c）無壁霞型

3壁金タイフ

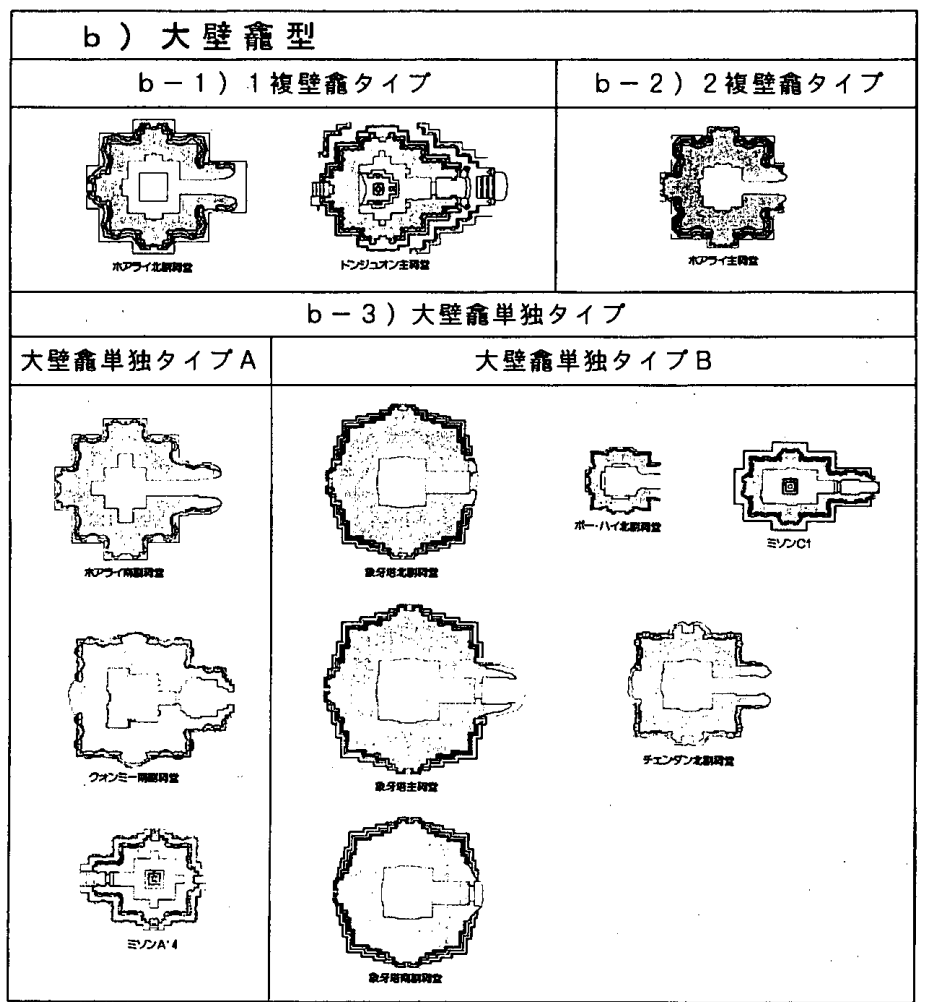

図-7 壁䧻の種類と構成

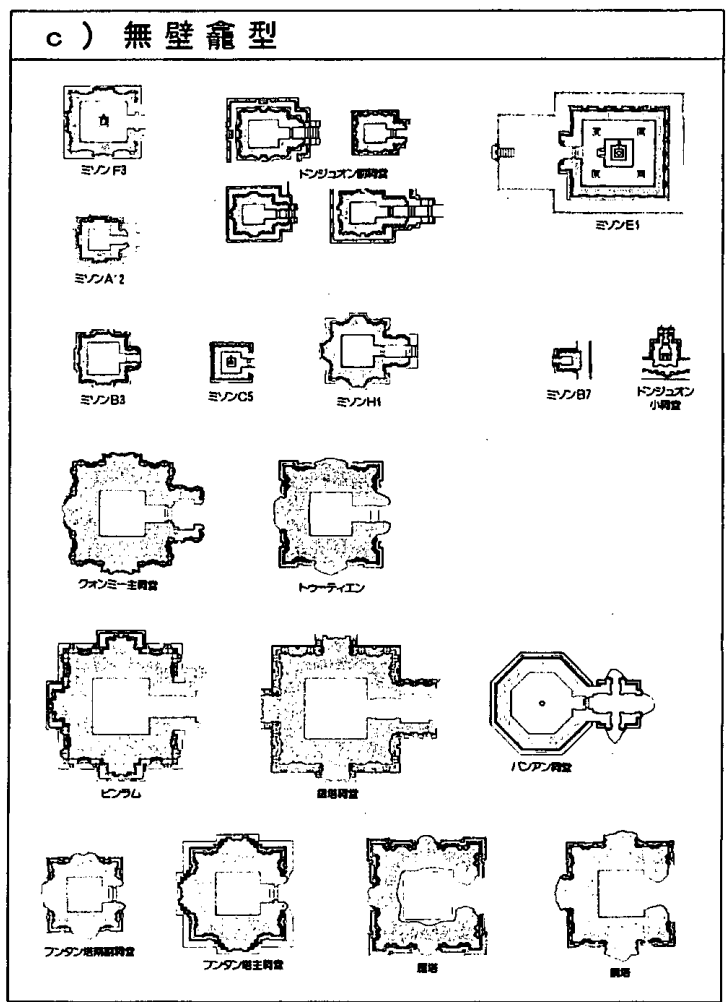

$\mathrm{S}=1: 850$ 
ウ)から離れた聖地に設けられたミソン遺跡群のように 限られた王族等によって儀式が執り行われた閉鎖的な宗 教存在から、都市と一体化した宗教施設への変化を示唆 している。このような観点から考えれば、壁霞を設けな いこ之は各時代の祠堂内での儀式形式の推移や、各遗構 の造営意図などと関係があったと考えられる。

\section{5.まとめ}

これまでに述へててきた壁䧻の種類と配置についての相 関を整理しておきたい。チャンパ建築の柌堂の壁青を、 壁䧻の数、方位、種類によって分類すると図一 7、表一 1 のようになる。チャンパ建築の同堂は、ほぼ矩形の主 房とその前に付属して設けられた前房によって構成され ているが、前房に壁竉を用いたのは、ミソンE 4 だけで ある ${ }^{22}$ 。それ以外の柌堂では、主房の壁面の 4 面のうち、 3 面もしくは 4 面に設けられており、壁雹は主房を中心 に配置されていた。さらに、壁䧻を設けない無壁俞型の 䄇堂もみられる。

次に、配置について整理すると、南、西、北の 3 面の

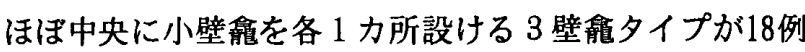
と最も多く、この形式は小壁龍を用いる䄇堂の基本形と みなすことができる。これを基本としてその他 9 例は 3 壁俞タイプに壁䧻を付加したと見なすことができる。

大壁弇型の事例は12例であり、10世紀中葉以降のミン ンA 1 様式からビンティン様式では、形骸化して規模が 小さくなる。

無壁弇型は17例あり、年代にばらつきがある。各時代、 各地域に壁䧻のある祠堂が存在することから、壁竉の機 能が失われて無壁俞型が生まれるのではなく、意図的に 壁䧻が設けられなかったと考えられる。この問題につい ては主要な宗教施設が都市施設と組み合わされて造営さ れるようになる10世紀以降(ミソンA 1 様式期からビン ティン様式期)の変化で、この時期に無壁弇型が17例中1 3例を占めている。

以上これまでに判明した呞堂の壁俞の特徽について、 以下に整理しておく。

1)チャンパ建築の阔堂において壁䧻は原則として主房 内壁面に設けられた。壁而を前房内壁面に設けた事 例はミソンE 4 だけである。

2 )壁雹で用いられているレンガの仕上げ面と、施工状 態から判断すると、壁䧻は建設当初に計画されて施 工されている。

3 )壁匬の配置は、南、西、北の 3 面のほぼ中央に小壁

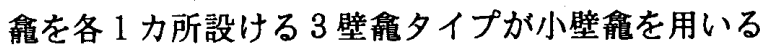
祠堂の基本形である。この 3 壁能タイプを基本とし て、いくつかの壁雪を付加したタイプがある。

4 )大壁全型の事例は11世紀までは北部と南部に共通し てみられるが、11世紀以降のビンティン様式期には
は奥行が小さくなり形骸化している。大壁雮型の䄇 堂はミソンA・4を除けば、すべてが東面している。 5 ) 11 世紀以降に造営されたビンティン地区 ${ }^{23}$ の齐堂の 多くが壁䧻を持っていない。ビンティン地区の遺構 の多くは、丘上に配置され遠望を重視した造形で、 内部での儀式性が希薄になった傾向を示している。 6 )壁臂の構造には、連続聥減型と段首聥減型の 2 種類 があるが、後者が多用される。

歴史的建造物の内部空間の变遷については、その用途、 宗教体系の質的変化に伴う儀式の変容、建築構造技術の 進展などと密接に関係する。壁鸽の配置には、各方向を 示す方位神と密接な関係を持っていたとする指摘もある $* 24$ 。今後、用途の特定などの研究の進展が必要とされる。

本稿は実地調查によって資料の得られた壁雹の配置を 中心に整理したが、今後は壁雹の施工技術等の詳細につ いて考察を加えたい。

\section{参孝文触}

（1）Ｇ．セテス 山本智教訳『東南アジア文化史』1989．大藏出版

（2）. 石井米雄他、『東南アジア世界の形成」 1985. 講談社

（3）大大林太良編『東南アジアの民族と歴史』1984. 山川出版社

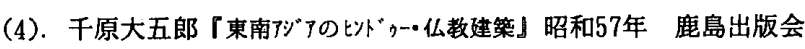

（5）、ベト社会科学院編 石澤良昭他訳『チャム彫刻』1988. 連合出版

（6）。桃木至郎他「チャンパ王国の息跡と文化」（財）トヨ夕剘団 1994.

(7). H. Parmentier, IInventaire descriptif Des Monuments câms de L'Annam」4vols. 1909-1918. E. F.E. 0.

(8). Ph. Stern『' 'Art du Champa et son Èvolution』Toulouse 1942.

(9). J. Boisselier 「La Statuaire du Champa」 Pàris 1963. E.r.e.o.

(10). G. Maspero ILe Royaume de Champa」Paris et Bruxelles 1928.

(11). R. C. Majumdar, 『CHAMPA History \& Culture of an Indian colonia1 Kingdam in the far East2nd-16th century A. D. $』$ Gian Publihing Hause Reprinted. 1985.

(12). Tran Ky Phuong, rCham Ruins」 The GIOI Hanoi 1993.

\section{注 眍}

1）チャンパは2 世紀末からインドと中国を結ぶ中継交易国家とし て栄えた王国て、ヒンドゥ一教・仏教の神々を祀る宗教建築を 200棟以上も建立した。チャンパ王国は15世紀末まで東南アジ アの中継貿易の拠点として栄えたが、11世紀頃から越族の南下 によって南部のウィジャヤ地域へ王国の中心が移動し、15世紀 には王国は実質上隇びた。参考文献(2)p. 56〜p. 104. (3)p. 174 〜p. 178. p. 212〜p. 223. これに対して桃木至郎は、「18世 紀までチャンパ王国の 2 つのグループの内、海洋系のグループ は各地て積極的に商業活動を行っていた」と指摘している。 「新しいチャンパ史」参考文献(6)p. 65〜p. 72.18世紀まで 実質的なチャンパ人の活動は認められるが、15世紀に王国が本 格的な宗教建築を造営できなくなったとみなし、15世紀末を衰 亡期とする。本稿てはこのチャンパ王国時代に造営された組積 
造宗教建築を総称して「チャンパ建筑」または「チャンパ阔堂」 と表現する。

2) フランス極東学院はフランスのアジア地域研究機関。フランス 領インドシナ時代にサイゴンから1900年にハノイに移されて設 立。インドシナ、中国、日本、インドを対象とし考古発掘、碑 文調查、遗跡の保存修復、言語、民族調查などの研究を行って いる。同学院 (E. F. E. 0.) の研究者達は装飾された柱形部分を、 pilastre亡呼んている。(英) Pilaster Ph. Stern 参考文献(8) P. 23 組積造であるチャンパ建築ては、柱として構造を支持 するのではなく壁全体で上部構造を支えている。

3) フランス人研究者はentre pilastre(英:inter pilaster)之呼 んている。柱形と柱形の間の凹形の壁面を指す。

4) 20 世紀初頭からインドシナ地域を精力的に調查したフランス極 東学院の研究者は、中国史料「梁書」（諸蕃志末史通考巻上） 「隋書」に記載された「干闌」をチャム語のKâlanに比定して いる。これらの邦訳として本稿では千原大五郎の建築分類に従 って「阔堂」という呼称を用いる。参考文献(4)P.41 現在べ トナム人は泀堂（トードゥオン）と呼んでることからも冏堂 の語を用いる。さらに、1つの伽藍の中て酮堂が 1 棟の場合亡、 大小数棟設けられる場合がある。並立した呞堂の中央にあるも のを「主䣳堂」、その他の同堂を「副同堂」と呼ぶ。

5 ）この部分はカンボジアやインドネシアのレンガ建築ては盲屝と することが多い。チャンパ建築でも盲扉を設けたポー・ハイ主 阔堂があるが用例は少なく、新る女性の姿の彫像が設置される。

6)通常、壁䎱(niche)は「(1)壁を凹状に抰った部分てしはしばア ーチや半ドームで覆われる」（建築大辞典， $1993,1225 \mathrm{p}$ ）之 される。壁を抉って空間を造るという“形態上の意味”から、 本稿ては壁愈という言葉を広義の意味にとらえたい。さらに、 壁㓱の構造についても迫り出し構造を用いた特殊事例として、 壁離の概念に含めて用いる。「そこに彫像や花瓶が㯰かれる」 (同前揭書) との機能上からの視点からも壁憿という言葉は妥 当であろう。現在この部分を示すチャム語の呼称は残されてい ない。また、外壁面にも壁縚空間を設けている。その両者を区 分する場合にのみ外壁面のものを「外壁霞」内壁面のものを 「内壁㓱」と呼ふ。

7 ）チャンパの付属建築には、楼門、聖水庫、宝物庫、矩形房、碑 文庫などがあるが、チャンパ時代の呼称や用途についてはわか っていない。拙稿「ミーソン遺構の呼称之建築構成に関する一 考察」日本建筑学会大会学術梗概集 1991.

8) チャンパの宗教建築ではほとんどの建築物に外壁俞が設けられ れている。外壁愈の装飾の変化については、H. Parmentier、Ph. Sternが言及しているが、内壁閃はほとんど検討されていない。

9) チャンパ建筑の美術史分類については、参考文献(8)p. 13〜110。 本稿では各建物の建築年代はPh. Sternの考証によった。

10) チャンパの宗教建築物は、後世の增改筑や補修が多く施されて いる。そのため本来壁鹃のなかった壁面に、後世に内部壁面が 大幅に改造され、壁㓱が設けられた場合もあるとみられるが、 本稿では改造の明らかなものを除いて考察する。
11）チャム族の祭礼をカテ祭りと呼ぶこの祭りについてはTran $\mathrm{Ky}$ Phuong 「The Kalê new year's Festival of Cham Kthic in Ninh Thuân」に儀式内容が記されており、本稿はそれに従った。

12）人が踏み入れることが可能な、大きな凹所である大壁俞(walkin niche)を壁俞の範嗃に入れることは、一般に俱解を招く心 配がある。しかし、現在では機能も用途も特定できないことか ら、仮に大壁㓱という呼称を用いる。本来は内部空間を拡張す るために用いられた構造的手法で、外部壁面の形状と相関性を もって設けられたと考えられる。

13）大壁㰍の中に小壁㓱(small niche)を設置するものを、その小壁

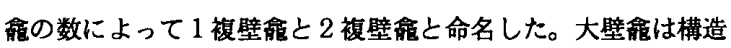
的に屋蓋の構造と強く関係しており、小壁艇は壁の構造の一部 であることからこれらを分雄して検討することにした。

14）迫り出し積みをhanging overと呼び、この構造をcorbel constructionとして統一して用いる。千原大五郎. 参考文献(4) p . 5 3〜 p. 58 アーチの技術の喼められているビルマなどの一部地 域を除けば、カンボジア、ウェトナム、ラオスの 14 世紀以前の 組皘造の宗教建策は、この迫り出し構造て屋蓋が支持される。

15）迫り出し全幅とは、迫り出し部分を全体としてとらえた場合に、 それぞれのレンガの迫り出した幅の合計をいう。

16）迫り出し全高は迫り出しの起点から迫り出しの終点までの高さ。

17）参考文献(8)p. 30〜 p. 39。クオンミ一の柱型や壁面にみられる 渦巻唐草の連続文様の浮き彫りは中部ジャワのチャンティ・カ ラサン（ 9 世紀中葉）上、菱形の連続花様文はカンボジアのプ リア・コー（879年）と極めて類似していると指摘している。

18） アンコール遣跡群の中にあるプラサット・クラヴァン遣跡の内 部にはヴィシュヌ神やラクシュミ一像などが内部壁面に彫刻さ れている。しかし、クメール遣跡でも開口部の砂岩彫刻などを 除く之内部には装飾は少なく、特に祠堂の主房壁面に彫刻を施 した事例は現在のところほかに見つかっていない

19）ソーマスートラとは、リンガや聖水などを外部に流す砂岩製の 桶、またはその桶の出入口に対する総称

20）ポー・ナガル主祠堂には木彫の象が壁霞の前方に配置されてい る。方位神に対する信仰からも大壁雹内に信仰の対象物が設置 されていた可能性が高い。

21）参考文献(8) vol III P1. Xl I、レXl U.にスケッチがある。

22）参考文献(8) volII P1. XY， $\chi X \mathbb{X}$.

23）参考文献(8) vol IV P1. LXXXIX 〜XC I . ミソン E 4 は米軍の直 拏弹を受け残っていない。前房に壁䡕があったことは、平面、 断面図にそれぞれ描かれていることから明らかてある。

24）ビンティン地区はサンスクリット語でウィジャヤと呼ばれた地 域て、11世紀以降に北部越族の圧迫を受け王国の中心が移る。

25） Tran Ky Phuong 参考文献(12) p. 23〜24 チャンパ建筑では方 位神として東には雷神インドラ、南西には火の神アグニ、南に はヤマ、北西にはウォリク、北東にはイシャーナ、南西にはブ ラフマー、北にはクウェーラの各神が祀られたとされている。

(1995年11月10日原稿受理，1996年 5 月 9 日採用決定) 